\title{
Effects of High-Pressure Technology on the Functional Properties of Milk and Fermented Milk Products
}

\author{
Tulay OZCAN ${ }^{1}$, Arzu AKPINAR BAYIZIT ${ }^{1}$, Lutfiye YILMAZ-ERSAN ${ }^{1}$ and Pinar AYDINOL ${ }^{2}$ \\ 1. Department of Food Engineering, Uludag University, Gorukle 16059, Bursa/Turkey \\ 2. Department of Food Technology, Mustafakemalpasa Vocational School, Uludag University, Mustafakemalpasa 16500, \\ Bursa/Turkey
}

\begin{abstract}
HPP (high pressure processing) is one of the novel technologies to produce microbiologically safe food. HPP is a non-thermal food processing method, wherein the food is subjected to a very high pressure ranging between 100-800 MPa in order to prevent undesirable chemical and microbiological reactions, and hence, prolong the shelf-life. HPP is also called as "high hydrostatic processing, ultra-high pressure processing or isostatic processing”. In dairy products, HHP has the potential to modify the functional properties of proteins, polysaccharides and alter biochemical reactions without significantly affecting the nutritional and sensory properties. HPP treatment induces significant changes in milk components particularly in proteins (whey proteins and caseins), as well as on their applicability in innovative dairy productions. HPP influences technological properties of various milk products such as firmness, water-holding capacity of the gel and network structure, cheese yield, rennet coagulation time and ripening.
\end{abstract}

Key words: High pressure technology, dairy foods, functional properties.

\section{Introduction}

Currently consumers worldwide are more demanding with regard to the quality and safety of the foods they consume, especially those that produce the perception of healthy products. To meet these demands, the food industry has improved its conventional heat preservation processes by developing continuous HTST (high temperature/short time), UHT (ultra high temperature) treatments and aseptic packaging systems. These products maintain a high standard of nutrition and flavor, while meeting the required safety level and achieving a long shelf life [1].

Alongside the development and increased consumption of minimally processed foods due to health consciousness, various preservation technologies have been emerged. Within this group of processes "non-thermal or cold or alternative

Corresponding author: Tulay Ozcan, Ph.D., Assoc. Prof., research fields: dairy processing, dairy products biochemistry and reology. preservation methods", which do not rely on heat for microbial and enzyme inactivation, will keep foods safe to eat, retain the sensory attributes and nutrient content to raw or fresh products. These non-thermal technologies include HHP (high hydrostatic pressure), OMF (oscillatory magnetic fields), PEF (pulsed electric fields), US (ultrasound), different forms of ionizing radiation (gamma, electron beam), gases (ozone, cold plasma, chlorine dioxide), light (ultraviolet, pulsed light) and chemical (chlorine, surfactants) sanitizers. Heat could be generated by some of these processes; however, the temperature increase will never reach the levels of a conventional thermal process and could be controlled with the help of a cooling station [2-5].

\section{Operational Technology and Mechanism of High Hydrostatic Pressure}

Probably the most developed and widely implanted technology at the industrial level is high hydrostatic pressure, in which food is subjected to pressures as high as 6,000 times the atmospheric pressure within 
the range of 100-800 $\mathrm{MPa}$. This technology has demonstrated its capability of retaining food quality with diverse benefits, including increased shelf life and maximized freshness and flavor [6, 7]. High pressure technology acts equally throughout a mass of food regardless of size, shape and composition. Thus, HHP is also called as "HPP (high pressure processing) or UHPP (ultra high pressure processing) or isostatic processing or pascalization”. High pressure is accomplished by the use of an isostatic pressure chamber which is filled with a hydraulic fluid, usually water. The product is packaged in a flexible container and placed in the chamber. Inside the chamber extreme pressures, up to $600 \mathrm{MPa}(87,000 \mathrm{psi})$, are applied and sustained usually for twenty minutes. This is done with minimalized physical and chemical alterations of the product. The isostatic compression will uniformly increase the temperature of food matrix approximately $3{ }^{\circ} \mathrm{C}$ per $100 \mathrm{MPa}[8,9]$.

HHP treatments have been used mainly for reducing microbial populations, especially pathogenic bacteria, by interrupting cell membrane integrity, due to temperature increase, which affects membrane permeability, DNA and protein denaturation and inactivation of cytoplasmic enzymes (Fig. 1) [10-14].

Applications include the preservation of meat products, oysters, fruit jams, fruit juices, salad dressings, fresh calamari, rice cake, duck liver, jam, guacamole, and many ready-to-eat foods. In all these cases, microbial and enzyme inactivation is achieved without altering the product quality (Table 1). In relation to the total percentage utilization of HHP equipment, vegetable products account for $28 \%$, meat products for $26 \%$, sea foods and fish for $15 \%$, juices and beverages for $14 \%$, and other products for $17 \%$ [6, $7,15]$.

\section{Application of High Pressure in Milk}

Milk, as being a functional perishable food, is generally subjected to heat treatment to obtain a safe and acceptable shelf life. However, heat could be destructive on natural nutrients and bioactive compounds [1, 16-18].

The main problems, observed during traditional milk pasteurization, sterilization and concentration are:

(1) The loss of desirable organoleptic properties, especially those related to the texture, color and flavor.

(2) The reduction of milk's nutritional value. Milk sterilization and concentration and in lesser extent milk pasteurization cause significant loss to vitamin B

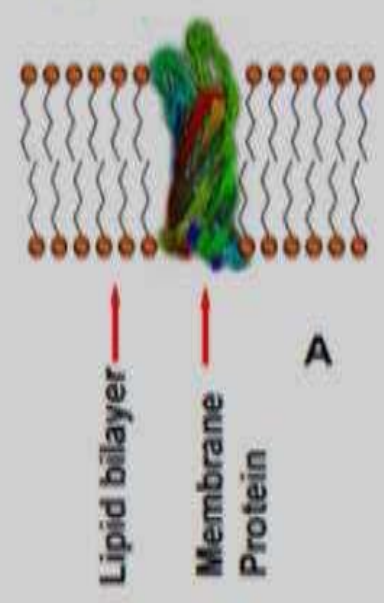

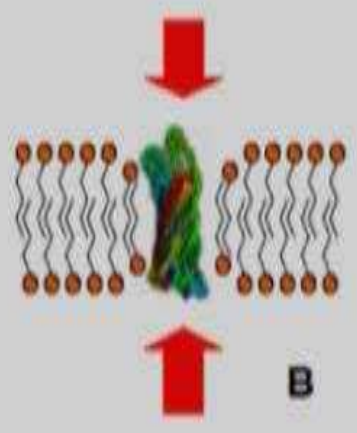

Hydrostatic Pressure Applied

(Interdigitated bilayer)

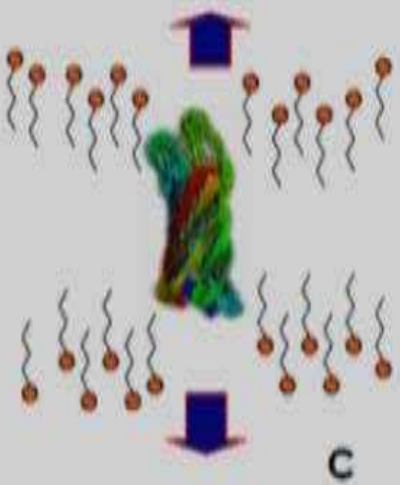

Hydrostatic Pressure Rapidly Released

Fig. 1 Effect of high pressure on cell membrane materials [2]. 
Table 1 Advantages and limitations of HHP applications in foods [1, 14, 22].

\begin{tabular}{|c|c|}
\hline Advantages & Limitations \\
\hline $\begin{array}{l}\text { Suitable for products with high water content and can be modified } \\
\text { for both batch processing and semi-continuous processing }\end{array}$ & $\begin{array}{l}\text { Food must contain water, as the whole phenomenon is based on } \\
\text { compression }\end{array}$ \\
\hline Significant inactivation of microorganisms, spores and enzymes & $\begin{array}{l}\text { Some enzymes could be very pressure resistant and some } \\
\text { spores might not be inactivated }\end{array}$ \\
\hline $\begin{array}{l}\text { Retain natural antimicrobial systems without changing the sensory } \\
\text { and nutritional quality of foods and extend shelf life up to } 2-3 \text { folds }\end{array}$ & \multirow{4}{*}{ Structurally fragile foods need special attention } \\
\hline $\begin{array}{l}\text { Significant reduction of heating which will minimize thermal } \\
\text { degradation of food components }\end{array}$ & \\
\hline $\begin{array}{l}\text { High retention of flavor, texture, color, nutritional value and } \\
\text { reduction in ice crystal formation }\end{array}$ & \\
\hline $\begin{array}{l}\text { Pressure is transmitted uniformly and instantly so that food product } \\
\text { retains its shape }\end{array}$ & \\
\hline Reduction of processing time & \multirow{2}{*}{$\begin{array}{l}\text { Could be a rate limiting step in most processing operations due } \\
\text { to changes in texture }\end{array}$} \\
\hline Process time is less dependenton on product shape and size & \\
\hline \multirow{2}{*}{$\begin{array}{l}\text { Reduced requirement of chemical additives, and increased } \\
\text { bioavailability }\end{array}$} & $\begin{array}{l}\text { Is not practiced because the installation cost is high for a } \\
\text { commercial scale }\end{array}$ \\
\hline & $\begin{array}{l}\text { The machinery required is complex and requires extremely high } \\
\text { precision in its construction, use and maintenance }\end{array}$ \\
\hline $\begin{array}{l}\text { Clean technology, flexible system for number of products and } \\
\text { operation }\end{array}$ & \multirow{3}{*}{$\begin{array}{l}\text { Substantial economic losses due to need for implementation of } \\
\text { comprehensive quality assurance programs to eliminate the } \\
\text { chemical and microbiological risks during processing }\end{array}$} \\
\hline $\begin{array}{l}\text { Potential for the design of new products due to the creation of new } \\
\text { textures, tastes and functional properties }\end{array}$ & \\
\hline $\begin{array}{l}\text { Development potential for packaging to withstand a change in } \\
\text { volume up to } 15 \% \text { followed by a return to its original shape without } \\
\text { losing seal integrity or barrier properties }\end{array}$ & \\
\hline
\end{tabular}

complex, polyunsaturated fatty acids, alteration and degradation of milk proteins, leading to the development of bad odor and flavor due to the production of sulfhydryl compounds, and production of Amadori compounds due to Maillard reactions.

Therefore, many studies have been conducted on the use of alternative preservation methods to increase safety and keep the quality of milk and dairy products. High pressure processing, being a promising "non-thermal" technology, has become one of the innovative food processing technologies most accepted by consumers. The main benefits of HPP are obtaining microbiologically safe food while avoiding undesirable changes in the sensory, physicochemical and nutritional properties of foods.

In dairy food processing HHP is used for milk stabilization and to define the pressure-induced structural modifications of the main milk constituents (caseins, whey proteins, fat globules, enzymes), inactivation of microorganisms, depression of freezing point of water, and recovery of lactose and proteins from dairy waste water (nutraceuticals, drugs, food additives [1, 7, 11, 19-22].

The RCT (rennet coagulation time), rate of gel formation, gel firmness, water-holding capacity of the gel and network structure are all affected as a result of the HHP treatment [14, 21, 23, 24].

The main aim of milk pasteurization is the destruction/inactivation of microorganisms. In the case of HPP, it has shown that pressures ranging between 300 and $600 \mathrm{MPa}$ can destroy yeasts, molds and most vegetative bacteria, including most infectious food-borne pathogens such as Escherichia coli, Salmonella and Listeria [7, 11].

The resistance of microorganisms to pressure is variable depending upon processing conditions (pressure, time, temperature and cycles), food constituents, its properties and the physiological state of the microorganism. Cells at their exponential growing stage are more sensitive to pressure than in the stationary phase. The bacterial spores are more resistant than vegetative cells [25]. On the other hand, pressures ranging around 50-300 $\mathrm{MPa}$ can cause bacterial spore germination. Germinated spores could 
then be killed by applying mild heat treatment [26]. Gram-positive microorganisms are more resistant to pressure than Gram-negative, e.g. Gram-positive organisms need an application of 500-600 $\mathrm{MPa}$ at $25{ }^{\circ} \mathrm{C}$ for $10 \mathrm{~min}$ to achieve inactivation while Gram-negative organisms can be inactivated with 300-400 MPa with the same time-temperature combination. At pressures $>1,000 \mathrm{MPa}$ even bacterial spores are killed. However, UHPP has not been used in sterilization processes yet [11, 27].

Pressurization of milk causes conformational changes in milk proteins. Milk proteins, in native state, are stabilized by covalent bonds (peptide and disulphide bonds), electrostatic interactions, hydrophobic interactions and hydrogen bridges. Covalent bonds are almost unaffected by HPP and hence primary structure of proteins remains intact during high pressure treatment. In case of whey proteins the amount of non-casein nitrogen in milk serum decreases with increasing pressure, suggesting denaturation and insolubilization. With the application of HHP the size and number of casein micelles increases (as casein micelle dissociates into sub-micelles due to weakening of hydrophobic and electrostatic interactions between sub-micelle and further aggregation of sub-micelle to big cluster) as spherical particles change to form chains or clusters of sub-micelles. Size distribution of spherical casein micelles decreases from 200 to $120 \mathrm{~nm}$; maximum changes have been reported to occur between 150-400 $\mathrm{MPa}$ at $20^{\circ} \mathrm{C}$ [1, 22, 27-29].

Furthermore, Needs et al. [28] stated that milk subjected to HHP treatment loses its white color and turns to yellowish due to reduction in size of casein micelles.

Lactose in milk and milk products may isomerize to lactulose by heating and then degrade to form acids and other sugars. No changes in these compounds have been observed after pressurization (100-400 MPa for $10-60$ min at $25{ }^{\circ} \mathrm{C}$ ) suggesting no Maillard or lactose isomerization reaction occurs in milk after pressure treatment [21].

High pressure treatment also enhances pepsin hydrolysis of $\beta$-LG ( $\beta$-lactoglobulin) at $400 \mathrm{MPa}$, reduction in antigenicity and IgE (immunoglobulin E) binding of $\beta$-LG, which further opens the possibility of obtaining hypoallergenic hydrolysates of $\beta$-LG [30]. Felipe et al. [31] reported that pressure treatment of $500 \mathrm{MPa}$ at $25{ }^{\circ} \mathrm{C}$ denatured lactoglobulin, lactalbumins and immunoglobulins only at the highest pressures, particularly at temperatures above $50{ }^{\circ} \mathrm{C}$, which is an alternative to preserve colostrum immunoglobulins.

In addition to extension of shelf-life and preventing undesirable reactions, a further interesting area for HHP in dairy science is in the structuring or texturizing of dairy products e.g., concentrated or gelled products like cheese, yogurt, or ice cream.

\section{Application of High Pressure in Yogurt}

Under heating conditions, the two major whey proteins in skim milk, $\beta$-LG and $\alpha$-LA ( $\alpha$-lactalbumin), are irreversibly denatured and aggregated when the temperature is increased above about $70{ }^{\circ} \mathrm{C}$, and these reactions occur under conditions where hydrophobic interactions are enhanced, calcium and phosphate solubility is diminished, and relatively small changes to casein micelles sizes occurring. Under high pressure conditions, hydrophobic interactions are unfavorable, the solubility of calcium and phosphate is increased, and the casein micelle structure is substantially disrupted. Furthermore, $\beta$-LG significantly has lower stability than $\alpha$-LA. In particular, the treatments above $100 \mathrm{MPa}$ at ambient temperature could result in gradual denaturation of $\beta$-LG, while the $\alpha$-LA and BSA are stable up to 400 MPa. Therefore, the interactions between the denatured whey proteins and the other milk proteins might be different in pressure-treated and heat-treated milk leading variations in yogurt gel. Treatments at > 250 MPa could increase the casein micelle [11, 24, 32-34]. 
Yoghurt prepared from milk that was UHHP homogenized between 200 and $300 \mathrm{MPa}$ at $30-40{ }^{\circ} \mathrm{C}$ considering modifications induced in the fat fraction that could delay the lipid oxidation and lower the degree of lipolysis [35].

Acid gels, such as yogurt, obtained from HHP (400-500 MPa) homogenized milk showed increased yield stress, resistance to normal penetration, elastic modulus and reduced syneresis with decrease in whey holding capacity and retention of more than 20\% whey after centrifugation [36, 37]. Similarly, Needs et al. [27] recorded lower values of fracture stress in set yoghurts made from pressure-treated milk (60 MPa for $15 \mathrm{~min}$ ) compared to heat treated milk. Firmness of yoghurt made from HHP treated milk increased with increasing pressure, this may be linked to the fact that disruption of casein micelles, results in a greater effective area for surface interaction.

Yoghurt prepared from low fat milk and exposed to $300 \mathrm{MPa}$ for 10 min prevented after-acidification and significantly improved shelf life. Acidification of yoghurt milk with GDL (glucono- $\delta$-lactone) at 200 $\mathrm{MPa}$ for $20 \mathrm{~min}$ resulted in fine coagulum, homogeneous gel than that of heat treated milk [19, 22, 36].

\section{Application of High Pressure in Cheese}

Milk pasteurization inactivates pathogenic and almost all spoilage microorganisms, and is important to provide acceptable safety and quality of dairy products. Although conventional heat treatment has adverse effects with respect to many sensory characteristics of cheese, leading to alterations in texture and often delayed maturation, HHP could be used to produce high-quality cheeses [38].

HHP processing of milk causes whey protein denaturation and micelle fragmentation, and also alters mineral equilibrium. It has been observed that denaturation of whey proteins results in interaction between denatured whey protein and casein, which in turn increases the retention of former within casein matrix of cheese. Thus, these changes could lead to modifications of the technological parameters of milk used in cheese-making to improve the rennet coagulation properties and cheese yield (Fig. 2) [19, 36].
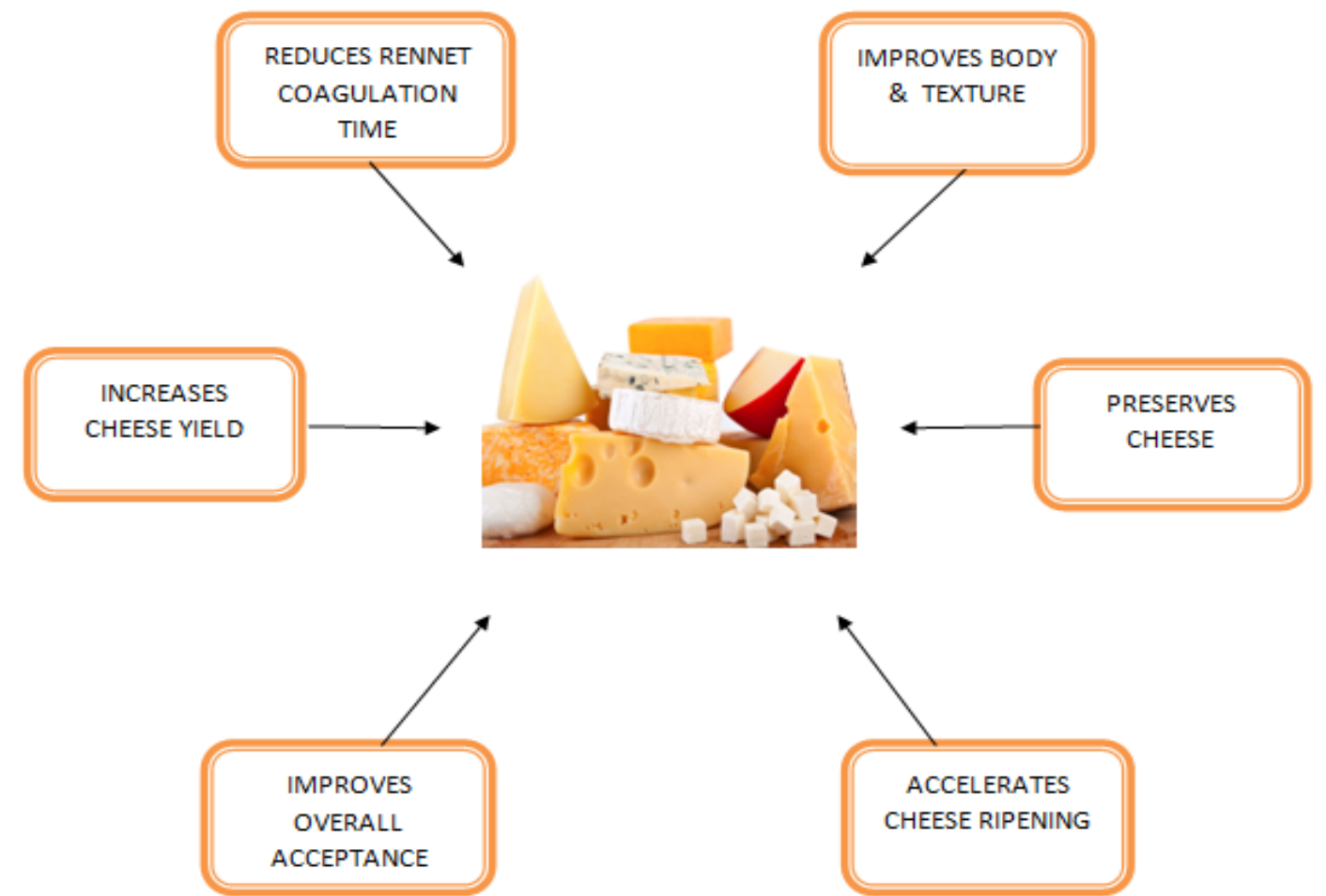

Fig. 2 Impact of HHP on cheese properties [22, 29]. 
RCT (rennet coagulation time), is the time at which the milk coagulum becomes firm enough for cutting after rennet addition. Needs et al. [27] stated that RCT was reduced markedly due to pressure exposure at 200 MPa. The decreased RCT was interrelated to the reduction in casein micelle size which led to increased specific surface area with increased probability of interparticle collision. However, at high pressure (400 $\mathrm{MPa}$ ), with RCT increased the denatured whey proteins were incorporated into the gel and their presence interfered with secondary aggregation phase, thus, again reduced the overall rate of coagulation.

Milk treated at 300-400 MPa significantly increased wet curd yield by up to $20 \%$ and reduced both the loss of protein in whey and the volume of whey, by denaturation of $\beta$-LG and its incorporation in the curd. This led to a high cheese yield to the extent of 7\% [39]. Many pressure conditions such as 400-600 MPa for short time (5-15 min) or "low" HHP treatment (50 MPa) for long time (72 h) have been tested for accelerating cheese ripening. The enhancement effect was assumed to be caused by the release of starter enzymes and dense network [1, 40]. HHP treatments are able to accelerate cheese ripening by (i) altering enzyme structure, (ii) increasing $\mathrm{pH}$ (0.1 to 0.7 units) and modifying water distribution to promote conditions for enzymatic activity, and (iii) conforming changes in the case in matrix to make it more prone to the action of proteases and bacterial lysis promoting the release of microbial enzymes [41].

\section{Application of High Pressure in Ice-Cream}

For most dairy products, proteins are the most expensive ingredients and alternative technologies can offer opportunities for protein structuring for maximized functionality. HHP was used to give similar textural properties and stability with considerably less protein in ice cream mixes [20].

HHP treatment induced fat crystallization, shortened the time required to achieve a desirable solid fat content, and thereby, reduced the ageing time of ice-cream mix. Pressurization of $600 \mathrm{MPa}$ for 2 min improved whipping ability of cream due to better crystallization properties of milk fat [42]. Study with modified whey protein concentrate added at a concentration of less than $10 \%$ in ice-cream mix exhibited enhanced overrun and foam stability, confirming the effect of HHP on foaming properties of whey proteins in a complex system [43].

Water content of the food got compressed by about $4 \%$ at $100 \mathrm{MPa}$ and $15 \%$ at $600 \mathrm{MPa}$. Depression in freezing point of water observed at high pressure to $-4{ }^{\circ} \mathrm{C}$ to $-8{ }^{\circ} \mathrm{C}$ or $-22{ }^{\circ} \mathrm{C}$ at 50,100 or $210 \mathrm{MPa}$, respectively, thus enabling sub-zero food processing without ice crystal formation or forming very small ice crystals. Small ice crystal formation could be used to significantly control microbial activity, help quality improvement as well to extend the determined shelf life [20, 29].

\section{Conclusions}

The concept of "green consumerism", meeting the consumer demand for nutritious and fresh food along with improved food safety, has increased interest to the application of non-thermal preservation methods. High hydrostatic pressure is quite versatile in application. HHP could be utilized for processing of many food products due to the ability to preserve both the special organoleptic features and its nutritional value. HHP has the potential to be used in development of new generation of value added functional or nutraceutical foods with unique structures and economic benefits due to reduced ingredient costs. In dairy industry HHP offers exciting opportunities in accordance to the obtained physico-chemical, textural and sensory properties. New opportunities in preservation of dairy foods high in bioactive components such as colostrum and human milk by HPP treatment may be of interest to the entrepreneurs. The focus is on careful process design, intensive kinetic and nutritional evaluations for 
process development and monitoring. However, one should also keep in mind the safety and quality standards of the high pressure processed foods in order to insure the international quality standards and safety as well as evaluation of the full commercial potential.

\section{References}

[1] Chawla, R., Patil, G. R., and Singh, A. K. 2011. "High Hydrostatic Pressure Technology in Dairy Processing: A Review.” J Food SciTechnol. 48: 260-8.

[2] Patel, H. A., Carroll, T., and Kelly, A. L. 2008. "Nonthermal Preservation Technologies for Dairy Applications.” In Dairy Processing and Quality Assurance. Edited by Chandan, R. C. Kilara, A. Shah, N. P. Ames, IA: Wiley-Blackwell, 465-82.

[3] Gupta, S., and Abu-Ghanam, N. 2012. "Recent Advances in the Application of Non Thermal Methods for the Prevention of Salmonella in Foods." In Salmonella -A Dangerous Foodborne Pathogen, Edited by B. S. M. Mahmoud. In Tech, 287-304.

[4] Hirneisen, K., Reith, J. L., Wei, J., Hoover, D. G., Hicks, D. T., Pivarnick, L. F., and Kniel, K. E. 2014. "Comparison of Pressure Inactivation of Caliciviruses and Picornaviruses in a Model Food System." Innov. Food Sci. Emerg. Technol. 26: 102-7.

[5] Yikmis, S. 2016. "New Approaches in Non-thermal Processes in the Food Industry.” Int. J. Nutr. Food Sci. 5: 344-51.

[6] Kadam, P. S., Jadhav, B. A., and Machewad, G. M. 2012. "Review on the High Pressure Technology (HPT) for Food Preservation.” J. Food Process Technol. 3: 1-5.

[7] Torres Bello, E. F., Martínez, G. G., Ceberio, B. F. K., Rodrigo, D., and López, A. M. 2014. "High Pressure Treatment in Foods.” Foods. 3: 476-90.

[8] Dalai, S. R., and Sahu, J. J. 2010. "High Hydrostatic Pressure (HPP) in Food Processing: Design Aspects and Applications.” Assam University Journal of Science and Technology 6: 70-87.

[9] San Martin, M. F., Barbosa-Canovas, G. V., and Swanson, B. G. 2010. "Food Processing by High Hydrostatic Pressure.” Crit Rev. Food Sci. Nut. 46: 627-45.

[10] Considine, T., Patel, H. A., Anema, S. G., Singh, H., and Creamer, L. K. 2007. "Interactions of Milk Proteins during Heat and High Hydrostatic Pressure Treatments-A Review." Innov. Food Sci. Emerg. Technol. 8:1-23.

[11] Considine, K. M., Kelly, A. L., Fitzgerald, G. F., Hill, C., and Sleator, R. D. 2008. "High Pressure Processing E Effects on Microbial Food Safety and Food Quality.”
FEMS Micro. Lett. 281: 1-9.

[12] Huang, H. W., Lung, H. M., Yang, B. B., and Wang, C. Y. 2014. "Responses of Microorganisms to High Hydrostatic Pressure Processing.” Food Con. 40: 250-9.

[13] Rieto-Calvo, M., Prieto, M., Lopez, M., and Álvarez-Ordóñez, A. 2014. "Effects of High Hydrostatic Pressure on Escherichia coli Ultra-structure, Membrane Integrity and Molecular Composition as Assessed by FTIR Spectroscopy and Microscopic Imaging Techniques.” Molecules 19: 21310-23.

[14] Liepa, M., Zagorska, J., and Galoburda, R. 2016. "High-Pressure Processing as Novel Technology in Dairy Industry: A Review.” Res. Rural Develop. 1: 46-83.

[15] Torres Bello, E. F., Martínez, G. G., Ceberio, B. F. K., Rodrigo, D., and López, A. M. 2014. "High Pressure Treatment in Foods.” Foods. 3: 476-90.

[16] Mújica-Paz, H., Valdez-Fragoso, A., Samson, C. T., Welti-Chanes, J., and Torres, J. A. 2011. "High-Pressure Processing Technologies for the Pasteurization and Sterilization of Foods.” Food Bioprocess Tech. 4: 969-85.

[17] Neetoo, H., and Chen, H. 2012. "Application of High Hydrostatic Pressure Technology for Processing and Preservation of Foods.” In Progress in Food Preservation. Edited by R. Bhat, K. Alias, and G. Paliyath. Wiley-Blackwell, A John Wiley \& Sons Ltd. Publishers, 259-62.

[18] Tokusoglu, O., Swanson, B. G., and Barbosa-Canovas, G. V. 2015. "High Hydrostatic Pressure Processing for Improved Dairy Food Quality.” In Improving Food Quality with Novel Food Processing Technologies, Edited by Tokusoglu, O. and Swanson, B. G. CRC Press, Taylor and Francis, 33-62.

[19] Huppertz, T., Fox, P. F., and Kelly, A. L. 2004a. "High Pressure Treatment of Bovine Milk: Effects on Casein Micelles and Whey Proteins.” J. Dairy Res. 71: 97-106.

[20] Huppertz, T., Smiddy, M. A., Goff, H. D., and Kelly, A. L. 2011. "Effects of High Pressure Treatment of Mix on Ice Cream Manufacture.” Int. Dairy J. 21: 718-26.

[21] López-Fandiño, R. 2006. "High Pressure-Induced Changes in Milk Proteins and Possible Applications in Dairy Technology.” Int. Dairy J. 16: 1119-31.

[22] Chopde, S. S., Deshmukh, M. A., Kalyankar, S. D., and Changade, S. P. 2014. "Applications of High Pressure Technology for Milk Processing.” Res. J Animal Hus. Dairy Sci.5: 143-7.

[23] Smelt, J. P. P. M. 1998. "Recent Advances in the Microbiology of High Pressure Processing." Trend Food Sci. Technol. 9: 152-8.

[24] Donsi, G., Ferrari, G., and Maresca, P. 2011. "Rheological Properties of High Pressure Milk Cream." Procedia Food Sci. 1: 862-8.

[25] Gould, G. W. 2000. "Preservation: Past, Present and 
Future.” Br. Med. Bull 56: 84-96.

[26] Daryaei, H., Coventry, M. J., Versteeg, C., and Sherkat, F. 2006. "Effects of High Pressure Treatment on Shelf Life and Quality of Fresh Lactic Curd Cheese.” Aust J. Dairy Technol. 61: 186-8.

[27] Huppertz, T., Fox, P. F., de Kruif, K. G., and Kelly, A. L. 2006. "High Pressure-Induced Changes in Bovine Milk Proteins: A Review.” Biochim Biophys Acta 1764: 593-8.

[28] Needs, E. C., Stenning, R. A., Gill, A. L., Ferragut, V., and Rich, G. T. 2000. "High-Pressure Treatment of Milk: Effects on Casein Micelle Structure and on Enzymatic Coagulation.” J. Dairy Res. 67: 31-42.

[29] Naik, L., Sharma, R., Rajput, Y. S., and Manju, G. 2013. "Application of High Pressure Processing Technology for Dairy Food Preservation-Future Perspective: A Review.” J Anim Prod Adv. 3: 232-41.

[30] Chicon, R., Lopez-Fandino, R., Alonso, E., and Belloque, J. 2008. "Proteolytic Pattern, Antigenicity, and Serum Immunoglobulin E Binding of $\beta$-Lactogobulin Hydrolysates Obtained by Pepsin and High Pressure Treatments.” J. Dairy Sci. 91: 928-38.

[31] Felipe, X., Capellas, M., and Law, A. R. 1997. "Comparison of the Effects of High-Pressure Treatments and Heat Pasteurization on the Whey Proteins in Goat's Milk.” J. Agric Food Chem. 45: 627-31.

[32] Huppertz, T., Fox, P. F., and Kelly, A. L. 2004b. "Properties of Casein Micelles in High-Pressure-Treated Bovine Milk.” Food Chem. 87: 103-10.

[33] Huppertz, T., Grosman, S., Fox, P. F., and Kelly, A. L. 2004c. "Heat and Ethanol Stabilities of High-Pressure-Treated Bovine Milk.” Int. Dairy J. 14: 125-33.

[34] Anema, S. G., Lowe, E. K., and Stockmann, R. 2005. "Particle Size Changes and Casein Solubilisation in High-Pressure-Treated Skim Milk.” Food Hydr. 19: 257-67.
[35] Serra, M., Trujillo, A. J., Pereda, J., Gumais, B., and Ferragut, V. 2008. "Quantification of Lipolysis and Lipid Oxidation During Cold Storage of Yoghurts Produced from Milk Treated by Ultra-high Pressure Homogenization.” J. Food Eng. 89: 99-104.

[36] Harte, F. M., Luedecke, L., Swanson, B. G., and Barbosa-Canovas, G. V. 2003. "Low-Fat Set Yogurt Made from Milk Subjected to Combinations of High Hydrostatic Pressure and Thermal Processing.” J. Dairy Sci. 86: 1074-82.

[37] Hernandez, A., and Harte, F. M. 2008. "Manufacture of Acid Gels from Skim Milk Using High-Pressure Homogenization.” J. Dairy Sci. 9: 3761-7.

[38] Martínez-Rodríguez, Y., Acosta-Muñiz, C., Olivas, G. I., GuerreroBeltrán, J., Rodrigo-Aliaga, D., and Sepúlveda, D. R. 2012. "High Hydrostatic Pressure Processing of Cheese.” Comp. Rev. Food Sci. Food. 11: 399-416.

[39] Arias, M., Lopez-Fandino, R., and Olano, A. 2000. "Influence of $\mathrm{pH}$ on Effect of High Pressure on Milk." Milchwissenschaft 55: 191-4.

[40] Saldo, J., Sendra, E., and Guamis, B. 2001. "Hard Cheese Structure after a High Hydrostatic Pressure Treatment at 50 Mpa for 72 h Applied to Cheese after Brining.” Lait. 81: 625-35.

[41] Voigt, D. D., Chevalier, F., Qian, M. C., and Kelly, A. L. 2010. "Effect of High-Pressure Treatment on Microbiology, Proteolysis, Lipolysis and Levels of Flavour Compounds in Mature Blue-Veined Cheese.” Innov. Food Sci. Emerg. Technol. 11: 68-77.

[42] Huppertz, T., Kelly, A. L., and Fox, P. F. 2002. "Effect of High Pressure on Constituents and Properties of Milk." Int. Dairy J. 12: 561-72.

[43] Lim, S. Y., Swanson, B. G., Ross, C. F., and Clark, S. 2007. "High Hydrostatic Pressure Modification of Whey Protein Concentrate for Improved Body and Texture of Low Fat Ice-Cream.” J. Dairy Sci. 91: 1308-16. 